\title{
PENGARUH FAKTOR MAKRO EKONOMI, FAKTOR LIKUIDITAS DAN FAKTOR EKSTERNAL TERHADAP YIELD OBLIGASI PEMERINTAH INDONESIA
}

\author{
Hary S. Sundoro \\ Manajemen, Universitas Bunda Mulia \\ Disetujui 2 Maret 2018
}

\begin{abstract}
This research has been undertaken to delve more deeply about the movement of the government bond yield in Indonesia, which is important to be a reference to predict the bond market expectation. The movement of the government bond yield in Indonesia has been actually caused of a couple of factors, for instance macroeconomics, liquidity, and external. The data that has been used for this research is from January 2012 to July 2016. Therefore, according to the result of the unit root test and co-integration, VECM has become a suitable method for accomplishing this research. The outcome of this research, ultimately, has proved that the movement of the government bond yield in Indonesia for all tenor had been fluctuating on account of all variables that contained of macroeconomics, liquidity, and external. The variable that gives the largest contribution for the movement of the government bond yield in Indonesia is the coupon rate itself.
\end{abstract}

Keywords: bond yield, external, macroeconomics, liquidity, VECM

\begin{abstract}
ABSTRAK
Penelitian ini dilakukan untuk mengetahui pergerakan yield obligasi pemerintah Indonesia yang diperlukan sebagai acuan dalam melihat ekspektasi pasar obligasi. Pergerakan yield obligasi pemerintah Indonesisa disebabkan oleh beberapa faktor diantaranya faktor makro ekonomi, faktor likuiditas dan faktor eksternal. Data yang digunakan mulai dari Januari 2012 sampai dengan Juli 2016. Berdasarkan hasil uji akar unit dan uji kointegrasi, metode yang digunakan adalah VECM. Hasil penelitian menunjukkan yield obligasi pemerintah Indonesia untuk semua tenor akan bergerak secara fluktuatif karena disebabkan oleh semua variabel yang terdapat pada faktor makro ekonomi, faktor likuiditas dan faktor eksternal. Variabel yang memberikan kontribusi terbesar terhadap pergerakan yield obligasi pemerintah adalah tingkat kupon obligasi itu sendiri.
\end{abstract}

Kata kunci: eksternal, likuiditas, makro ekonomi, VECM, yield

\section{PENDAHULUAN}

\section{Latar Belakang}

Obligasi telah menjadi jalan keluar bagi kebanyakan pihak swasta mau pun pemerintah di dalam memenuhi kebutuhan dananya. Hal tersebut dimulai pada saat krisis ekonomi melanda Asia di tahun 1997 dan pasar obligasi domestik dapat menjadi

*Korespondensi Penulis:

E-mail: hsundoro@bundamulia.ac.id alternatif dalam pemenuhan kebutuhan dana (Piesse et al., 2007). Obligasi telah berperan penting bagi kebanyakan perusahaan baik itu perusahaan pemerintah mau pun perusahaan swasta. Begitu juga, pemerintah Indonesia sudah mulai memanfaatkan kegunaan dari obligasi dimana pemerintah Indonesia telah menerbitkan beberapa seri Surat Utang Negara (SUN) sebagai alternatif pembiayaannya. 
Para investor dan pelaku pasar menggunakan suatu tolok ukur supaya mengetahui perkembangan nilai portofolio obligasi yang dimiliki, dan caranya yaitu dengan memantau pergerakan yield
(Stander, 2005). Pergerakan yield bukan serta merta terjadi begitu saja. Seperti yang terlihat pada gambar 1, yield yang berubah tersebut pastinya ada beberapa faktor yang memengaruhinya.

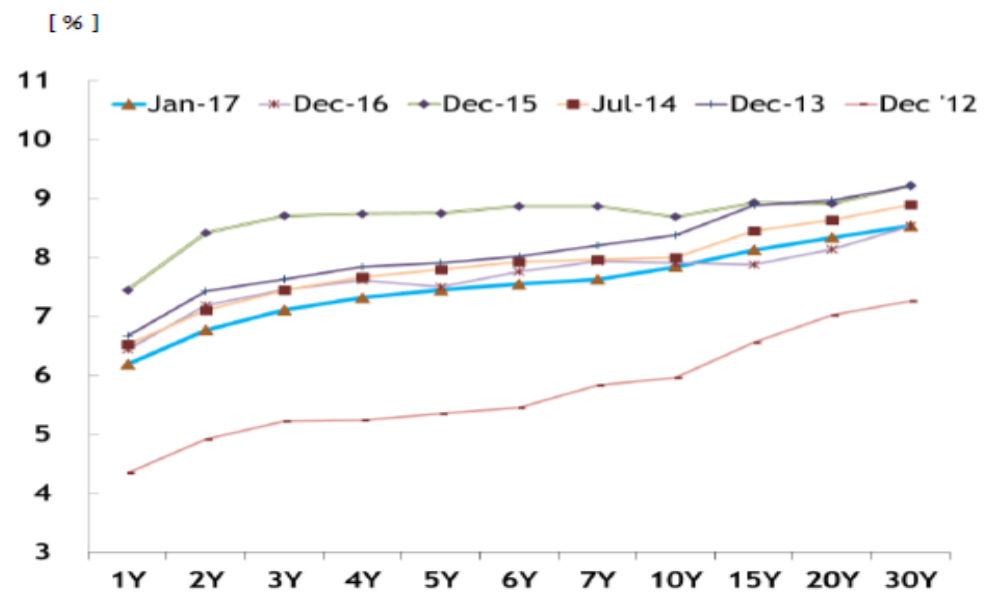

Gambar 1. Kurva Yield SUN Republik Indonesia

Sumber: Ditjen Pengelolaan dan Pembiayaan Risiko (DJPPR) per Februari 2017

Beberapa penelitian terakhir telah menautkan variabel-variabel fundamental makro ekonomi, faktor eksternal mau pun kondisi likuiditas dengan pasar obligasi. Kondisi makro ekonomi pada negara berkembang harus diperhatikan karena dapat juga menciptakan krisis ekonomi seperti yang terjadi di Asia tahun 1997, Rusia tahun 1998 dan Argentina tahun 2000 (Jurksas dan Kropiene, 2014). Suku bunga internasional dapat juga memengaruhi aliran modal ke dalam negara berkembang (Min, 1998). Artinya, kondisi pasar obligasi tidak hanya bergantung pada fundamental makro ekonomi, tetapi juga faktor pasar atau faktor eksternal. Kemampuan likuiditas suatu negara seperti cadangan devisa juga dapat memengaruhi pasar obligasi karena dapat menentukan kemampuan suatu negara membayar hutang-hutangnya (Baldacci et al., 2008).

\section{Tujuan Penelitian}

Penelitian ini dilakukan untuk mengetahui tujuan utamanya; Pertama, untuk meramalkan pengaruh faktor makro ekonomi (terdiri dari: tingkat bunga BI, inflasi, jumlah uang beredar dan IHSG) terhadap yield obligasi pemerintah Indonesia dari Januari 2012 sampai dengan Juli 2016. Kedua, untuk meramalkan pengaruh faktor likuiditas (terdiri dari cadangan devisa) terhadap yield obligasi pemerintah Indonesia dari Januari 2012 sampai dengan Juli 2016. Ketiga, untuk meramalkan pengaruh faktor eksternal (terdiri dari tingkat bunga acuan di Eropa) terhadap yield obligasi pemerintah Indonesia dari Januari 2012 sampai dengan Juli 2016.

\section{TINJAUAN PUSTAKA}

\section{Landasan Teori}

Beberapa penelitian telah menautkan variabel-variabel fundamental makro ekonomi dengan pasar obligasi. Negara-negara berkembang harus memperhitungkan risiko makro karena hal tersebut dapat menciptakan krisis ekonomi seperti yang terjadi di Asia tahun 1997, 
Rusia tahun 1998 dan Argentina tahun 2000 (Jurksas dan Kropiene, 2014).

Beberapa peneliti lainnya juga telah melakukan penelitian tentang yield dan makro ekonomi (Dewachter et al., 2006 dan Cochrane, 2001). Penelitian tentang yield obligasi dengan mempertimbangkan faktor makro ekonomi seperti pertumbuhan ekonomi, inflasi, jumlah uang beredar, nilai tukar Rupiah, tingkat suku bunga dan indeks saham juga telah dilakukan oleh Sihombing (2014).

Faktor eksternal dapat juga dianggap penting dalam memengaruhi pergerakan yield suatu obligasi. Adanya penelitian yang menemukan bahwa perubahan dalam sentimen pasar, tidak hanya bergantung pada fundamental makro ekonomi, tetapi juga faktor pasar atau faktor eksternal (Eichengreen dan Mody, 1998). Penelitian tersebut membahas tentang yield obligasi dapat dipengaruhi oleh rasio hutang terhadap tingkat ekspor dan peringkat obligasi.

Budina dan Mantchev (2000) meramalkan determinan dari harga obligasi Bulgaria dengan menggunakan data bulanan dari bulan Juli tahun 1994 sampai dengan bulan Juli tahun 1998. Salah satu simpulan dari penelitian tersebut adalah ekspor memiliki efek positif terhadap harga obligasi, sebaliknya nilai tukar nominal memiliki pengaruh yang negatif. Suku bunga internasional yang merupakan faktor eksternal dapat juga memengaruhi aliran modal ke dalam negara berkembang (Min,
1998). Artinya suku bunga internasional juga berpengaruh terhadap yield obligasi.

Kemampuan likuiditas suatu negara dapat menentukan kemampuan negara tersebut membayar hutang-hutangnya. Adanya penelitian yang menemukan besarnya cadangan devisa suatu negara dapat menjadi penanda bahwa negara tersebut dapat membayar hutang-hutangnya (Baldacci et al., 2008). Cadangan devisa juga memiliki efek positif terhadap harga obligasi seperti temuan dari Budina dan Mantchev (2000).

Sihombing (2014) meramalkan pergerakan yield obligasi dengan beberapa indikator. Hasil temuannya bersimpulan bahwa pasar obligasi memang memperhitungkan fundamental makro ekonomi saat menentukan yield obligasi. Akan tetapi faktor-faktor lain seperti faktor eksternal mau pun faktor likuiditas juga berperan penting terhadap perubahan yield obligasi.

\section{Rerangka Pemikiran}

Penelitian ini dilakukan dengan tujuan untuk meramalkan pengaruh faktor makro ekonomi, faktor likuiditas dan faktor eksternal terhadap yield obligasi pemerintah Indonesia. Faktor makro ekonomi dan faktor eksternal diberikan pembeda berdasarkan lokasi terjadinya. Faktor makro ekonomi lebih mewakili kondisi ekonomi dalam negeri dan faktor eksternal untuk luar negeri. Untuk lebih jelasnya rerangka pemikiran penelitian ini dapat ditunjukkan seperti pada gambar 2 di bawah ini.

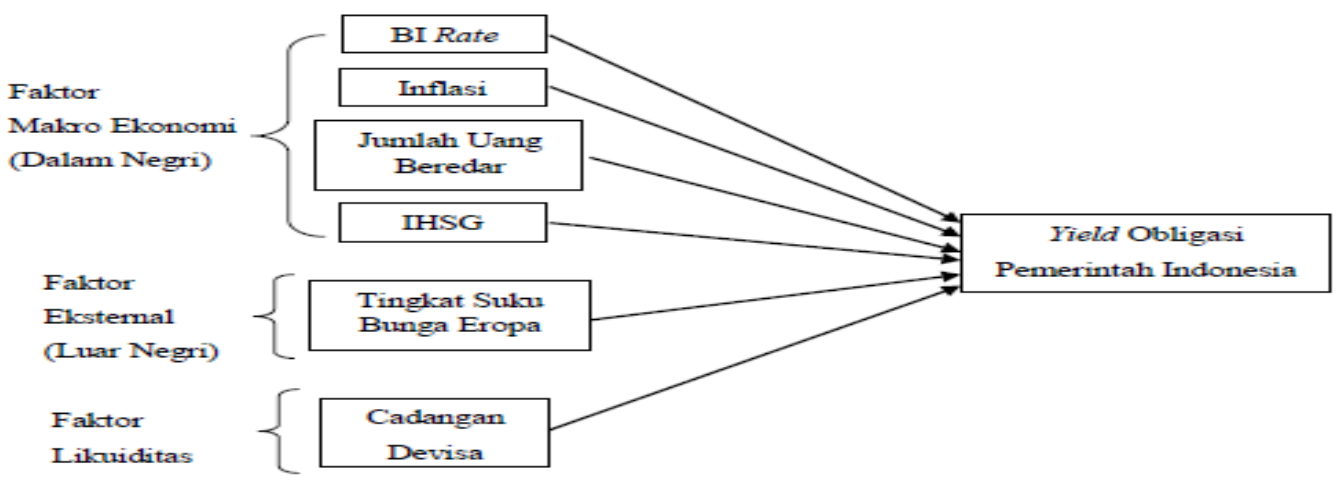

Gambar 2. Rerangka Pemikiran

Sumber: Peneliti, 2018 


\section{METODE PENELITIAN}

\section{Jenis dan Sumber Data}

Jenis data yang digunakan pada penelitian ini adalah data sekunder dalam bentuk time series (kurun waktu). Periode penelitiaannya dilakukan selama sekitar 4 tahun mulai dari awal tahun 2012 sampai dengan Juli 2016. Periode penelitian ini dimulai di tahun 2012 karena di awal tahun tersebut Indonesia mendapatkan kategori layak investasi oleh lembaga penilai internasional (Fitch dan Moody's). Periode penelitiannya diakhiri sampai Juli 2016 dikarenakan data variabel $\mathrm{BI}$ rate hanya sampai dengan Juli 2016. Pada Agustus
2016 dan seterusnya pemerintah lebih menggunakan acuan tingkat bunganya dengan BI 7day Repo Rate.

Data penelitian ini merupakan data sekunder berbentuk time series bulanan mulai dari Januari 2012 sampai dengan Juli 2016, sehingga jumlah total observasi yaitu 55. Sumber data diperoleh berdasarkan informasi yang dipublikasikan oleh lembaga-lembaga yang terkait. Lembagalembaga tersebut antara lain Bloomberg, Bank Indonesia (BI), dan Website investing.com. Pada umumnya, data yang digunakan pada penelitian ini dirangkum ke dalam tabel 1 .

Tabel 1. Jenis Data, Simbol, Satuan dan Sumber Data

\begin{tabular}{lllll}
\hline No. & \multicolumn{1}{c}{ Jenis Variabel } & \multicolumn{1}{c}{ Simbol } & Satuan & \multicolumn{1}{c}{ Sumber Data } \\
\hline 1. & $\begin{array}{l}\text { Yield } \text { Obligasi Pemerintah } \\
\text { Indonesia }\end{array}$ & YIELD & Persen & Bloomberg dan diolah \\
2. & $\begin{array}{l}\text { Tingkat suku bunga Bank } \\
\text { Indonesia }\end{array}$ & BIRATE & Persen & Bank Indonesia \\
3. & Inflasi & CPI & Persen & Bank Indonesia \\
4. & Jumlah uang beredar & M1 & Triliun Rp. & Bank Indonesia \\
5. & IHSG & IHSG & Ribuan Rp. & BEI \\
6. & Cadangan devisa & CD & Miliar US\$ & Bank Indonesia \\
7. & European Central Bank & ECB & Persen & Investing.com \\
\hline
\end{tabular}

Sumber: Gabungan beberapa sumber, 2016

Seperti yang terlihat pada tabel 1 bahwa satuan ukur pada data di semua variabel penelitian ini memiliki perbedaan. Beberapa variabel memiliki data dengan satuan persen, tetapi beberapa variabel lainnya memiliki data dengan satuannya dalam nilai mata uang. Oleh karena itu untuk menyamakan satuan ukur pada data di semua variabel penelitian ini, maka satuan ukur semua data diubah ke dalam satuan persen supaya menyamakan dengan satuan variabel yield obligasi pemerintah.

\begin{abstract}
Alat Analisis
Teknik analisis data pada penelitian ini menggunakan VAR (Vector Auto Regression) atau VECM (Vector Error Correction Model) karena kedua metode ini dapat dilakukan jika data penelitian merupakan data time series. VAR digunakan jika data yang diperoleh adalah stasioner pada tahap aras (level) dan tidak terdapat kointegrasi. VECM digunakan jika data yang diperoleh kemudian stasioner pada tahap turunan dan terdapat kointegrasi (Verbeek, 2000). Uji stasioneritas merupakan uji yang sangat penting dalam
\end{abstract}


analisis time series karena uji tersebut dapat menunjukkan validitas sebuah pengukuran.

Data pada penelitian ini telah stasioner pada tingkat turunan pertama dan terdapat kointegrasi yang artinya teknik analisis data pada penelitian ini akan menggunakan VECM. Model VECM digunakan dalam penelitian ini karena kemampuannya dalam menyediakan alatalat analisis seperti Impulse Response Function (IRF), yang digunakan untuk mengetahui berapa lama pengaruh guncangan dari satu variabel terhadap variabel yang lain tersebut terjadi, dan Forecast Error Variance Decomposition (FEVD), yang digunakan untuk memperkirakan persentase kontribusi masing-masing variabel terhadap perubahan variabel tertentu.

Secara umum, model persamaan regresi dalam VECM dapat dituliskan sebagai berikut (Verbeek, 2000) :

$\Delta Y_{t}=\sum_{i-1}^{k-1} \Gamma_{t} \Delta Y_{t-1}-\gamma \beta Y_{t-1}+\varepsilon_{t}$

Keterangan:

$\Gamma=$ Koefisien keterhubungan jangka pendek

$\beta=$ Koefisien keterhubungan jangka panjang
$Y=$ Kecepatan menuju keseimbangan (speed adjustment)

$Y_{\mathrm{t}}=$ Variabel-variabel endogenous yang digunakan dalam model

\section{HASIL DAN PEMBAHASAN}

\section{Analisis Impulse Response Function (IRF)}

Uji IRF menunjukkan bagaimana tanggapan dari setiap variabel endogen sepanjang waktu terhadap kejutan dari variabel itu sendiri dan variabel endogen lainnya. Selain itu, IRF juga digunakan untuk mengetahui berapa lama pengaruh guncangan dari satu variabel terhadap variabel yang lain tersebut terjadi.

\section{BI Rate terhadap Yield Obligasi}

Dari gambar 3 dapat diketahui bahwa perubahan BI rate menyebabkan yield tenor 2 tahun, 5 tahun dan 10 tahun menanggapi secara positif. Hasil uji IRF pada gambar 3 berarti telah sesuai dengan teori dari Jurksas dan Kropiene (2014). Pada saat tingkat bunga sedang naik, maka harga obligasi pemerintah akan turun karena tingkat keuntungan yang diharapkan (expected return) juga turut naik atau dapat dikatakan yield juga sedang naik.

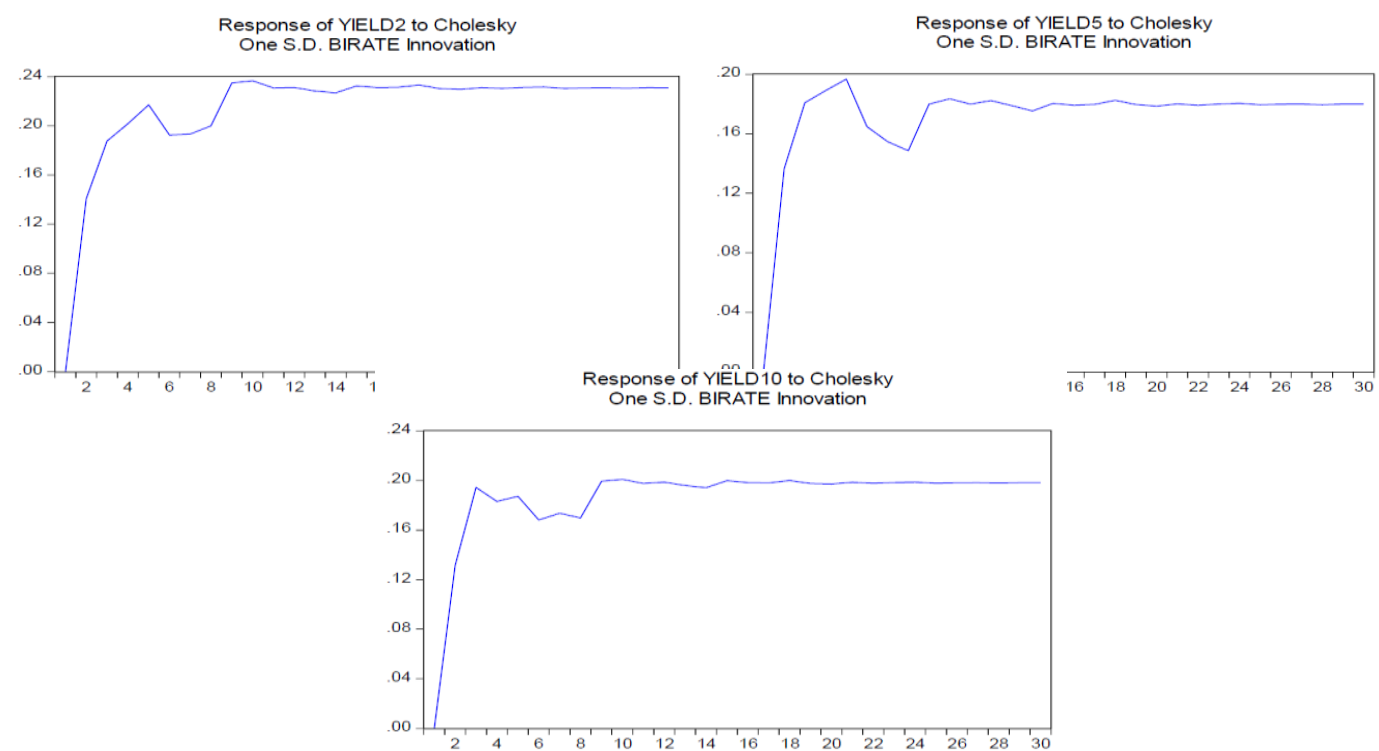

Gambar 3. Pengaruh BI Rate terhadap Yield Obligasi Pemerintah Indonesia

Sumber: E-Views, data diolah 2018 
BI rate dapat memberikan dampak positif terhadap pergerakan yield untuk obligasi jangka panjang mau pun obligasi jangka pendek (Sihombing, 2014). Pernyataan tersebut berarti sudah sesuai dengan gambar 3 yang menunjukkan kenaikan pada BI rate dapat menyebabkan yield semua tenor obligasi akan turut naik. Kebijakan moneter yang ketat diduga akan meningkatkan ekspektasi imbal hasil, sehingga kenaikan BI rate diduga akan meningkatkan yield obligasi.

\section{Inflasi (CPI) terhadap Yield Obligasi}

Hasil uji IRF pada gambar 4 menunjukkan bahwa yield obligasi dengan tenor 2 tahun, 5 tahun dan 10 tahun menanggapi perubahan yang terjadi pada CPI. Hasil temuan ini sesuai dengan teori dari Chionis et al., (2014) yang menyatakan bahwa inflasi dapat memengaruhi yield obligasi di Yunani pada saat sebelum mau pun sesudah krisis ekonomi. Hasil temuan lain juga menyatakan bahwa adanya pengaruh dari inflasi terhadap yield (Jurksas dan Kropiene, 2014; dan Baldacci et al., 2008).

Berdasarkan temuan-temuan tersebut dapat dikatakan bahwa pada saat inflasi naik, maka hal tersebut dapat mengindikasikan sedang terjadinya kenaikan daya beli dimana hal ini akan menyebabkan harga surat-surat berharga swasta mau pun pemerintah naik. Ketika harga obligasi naik, maka hal tersebut mengindikasikan yield sedang turun. Oleh karena itu berarti pada saat inflasi naik, maka yield akan turun.
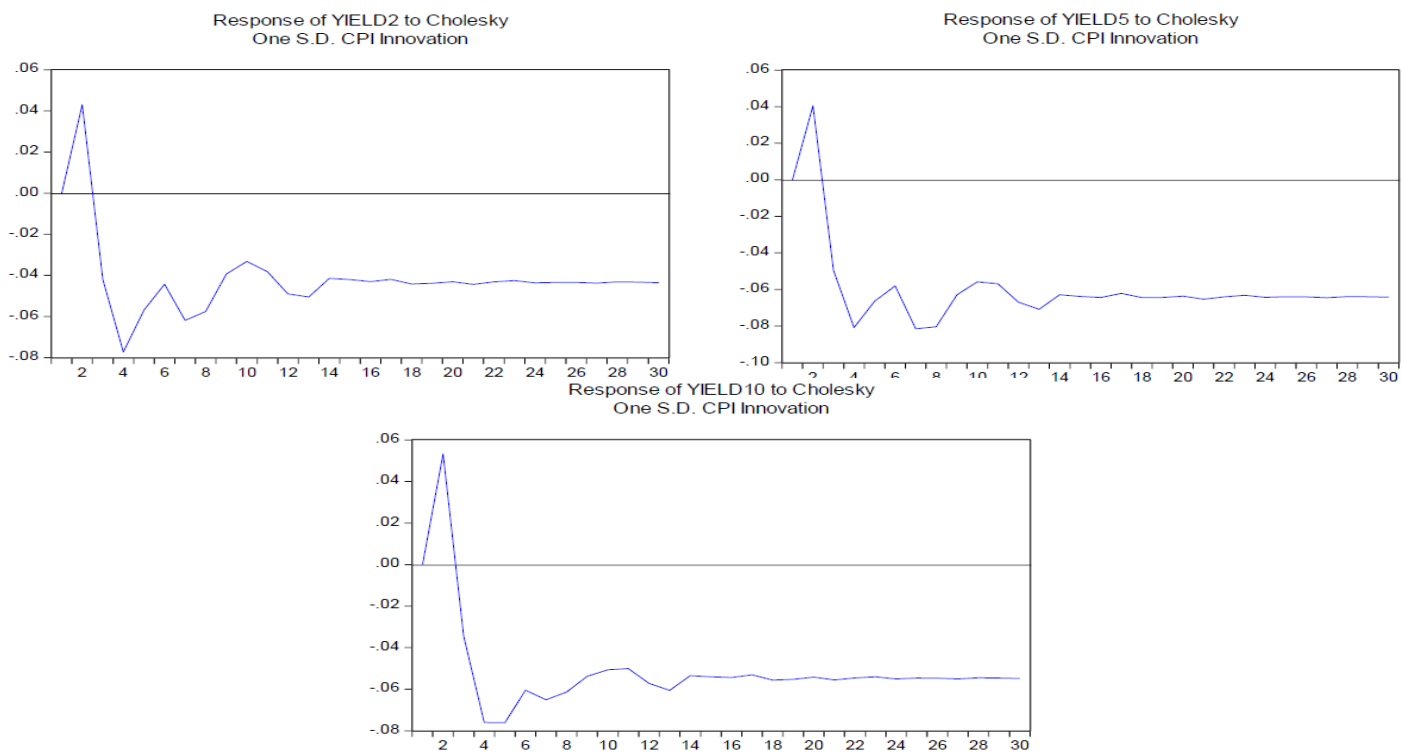

Gambar 4. Pengaruh CPI terhadap Yield Obligasi Pemerintah Indonesia Sumber: E-Views, data diolah 2018

\section{Jumlah Uang Beredar (M1) terhadap Yield Obligasi}

Dari gambar 5 dapat disimpulkan bahwa guncangan M1 dapat ditanggapi negatif oleh yield obligasi pemerintah di semua tenor. Hal tersebut sesuai dengan temuan dari Fah (2008) yang menyatakan jumlah uang beredar memengaruhi negatif signifikan terhadap pergerakan yield obligasi pemerintah Malaysia (Malaysian Government Securities - MGS). Pada saat jumlah uang beredar meningkat, maka hal tersebut akan menyebabkan peningkatan likuiditas dan menyebabkan pembayaran obligasi akan lancar. Harga obligasi akan mengalami peningkatan yang akhirnya yield akan turun. Berarti, adanya pengaruh yang negatif yang disebabkan oleh jumlah 
uang beredar terhadap yield obligasi pemerintah pada semua tenor.

Pengaruh negatif jumlah uang beredar terhadap yield obligasi juga sesuai dengan temuan dari Vargas (2005). Jumlah uang beredar yang semakin meningkat mempresentatifkan keadaan ekonomi yang sedang baik. Hal tersebut mengindikasikan pemerintah mampu membayar hutanghutangnya yang akhirnya harga obligasi pemerintah akan naik dan yield-nya turun.

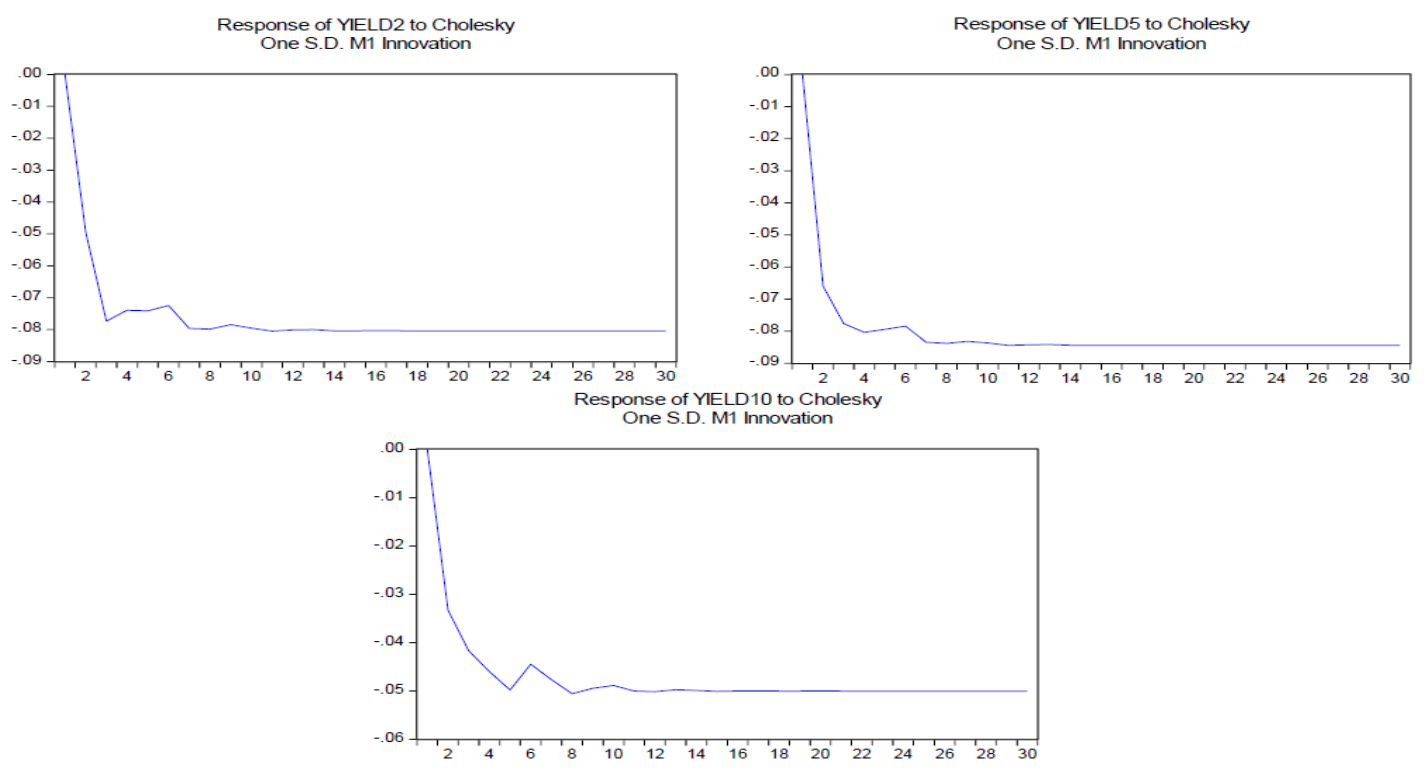

Gambar 5. Pengaruh JUB - M1 terhadap Yield Obligasi Pemerintah Indonesia Sumber: E-Views, data diolah 2018

\section{IHSG terhadap Yield Obligasi}

Hasil uji IRF pada gambar 6 menunjukkan bahwa IHSG memengaruhi secara negatif terhadap yield obligasi pemerintah di semua tenor mulai dari awal periode sampai keseimbangan jangka panjang. Hal ini sesuai dengan temuan dari Sihombing (2014) yang menyatakan yield obligasi jangka pendek mau pun jangka panjang menanggapi negatif terhadap perubahan IHSG. Temuan tersebut sejalan dengan studi Batten et al., (2006) yang menyatakan bahwa pasar saham dapat memengaruhi secara negatif yield pada pasar obligasi.

Dua temuan tersebut berarti sesuai dengan teori yang dikemukakan oleh $\mathrm{Li}$ (2006) yang menyatakan Price-earning ratio (P/E) di suatu pasar saham akan berbanding terbalik dengan yield pasar obligasi. Hal ini menunjukkan pada saat IHSG sedang naik, maka pasar saham sedang dalam kinerja yang baik. Oleh karena itu para investor akan lebih memilih berinvestasi di pasar saham ketimbang di pasar obligasi, sehingga yield obligasi akan turut turun. 


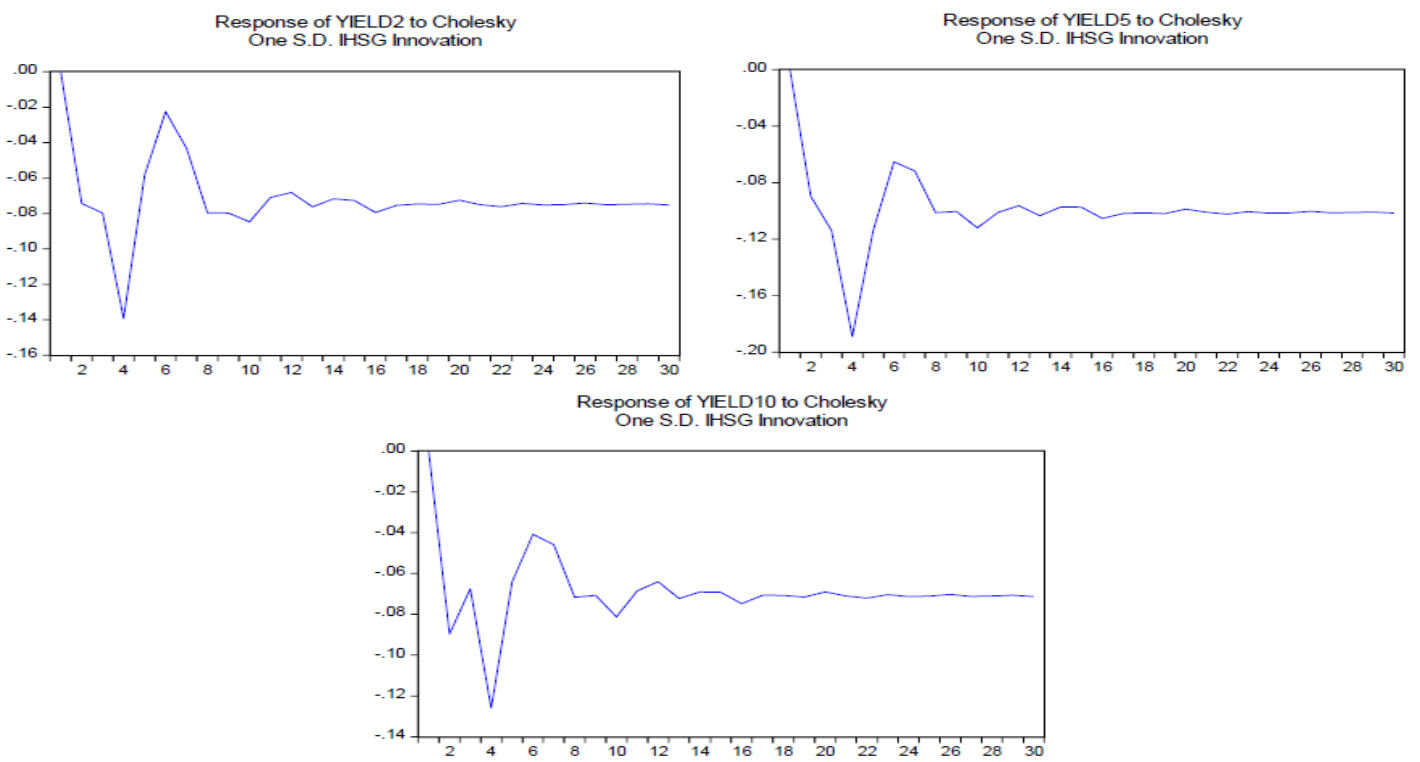

Gambar 6. Pengaruh IHSG terhadap Yield Obligasi Pemerintah Indonesia Sumber: E-Views, data diolah 2018

\section{Cadangan Devisa terhadap Yield Obligasi}

Dari gambar 7 pada hasil uji IRF, perubahan pada devisa dapat memengaruhi secara positif terhadap yield obligasi pemerintah semua tenor dari awal periode sampai dengan keseimbangan jangka panjang. Baldacci et al., (2008) menyatakan bahwa besarnya cadangan devisa suatu negara dapat menjadi penanda bahwa negara tersebut dapat membayar hutanghutangnya. Jika suatu negara semakin mampu membayar hutangnya, maka harga obligasi negara tersebut akan naik dan yield obligasinya akan turun.

Gandhi (2006) juga menyatakan bahwa apabila pengelolaan cadangan devisa lebih mementingkan kemampulabaan, maka komposisi portofolio investasi sebagian besar akan berbentuk portofolio obligasi yang memiliki yield tinggi. Artinya, pada saat cadangan devisa bertambah besar, maka yield obligasi akan turut naik.

Hal tersebut terjadi karena cadangan devisa yang digunakan suatu negara untuk kepentingan kemampulabaannya, maka negara tersebut menggunakan dananya untuk diinvestasikan ke dalam surat-surat berharga lainnya. Oleh karena itu hal tersebut dapat menunjukkan negara yang bersangkutan belum tentu dapat membayar surat-surat hutangnya walau pun cadangan devisanya besar, sehingga harga obligasi akan turun dan yield-nya naik. 

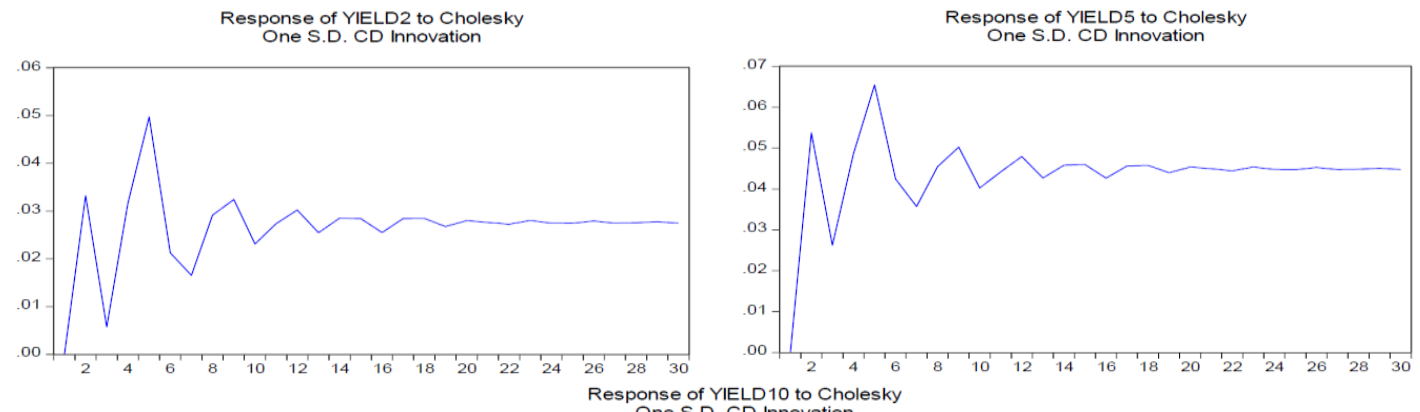

One S.D. CD Innovation

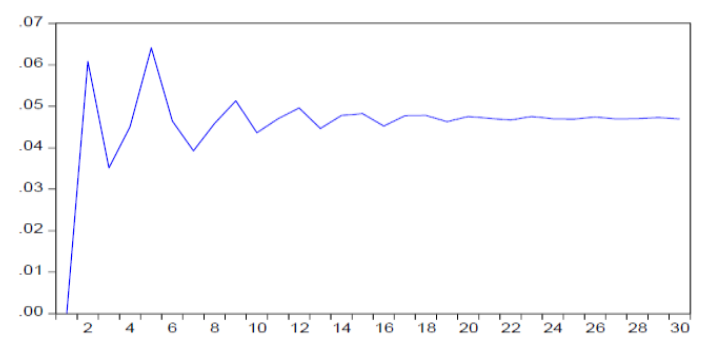

Gambar 7. Pengaruh Cadangan Devisa terhadap Yield Obligasi Pemerintah Indonesia

Sumber: E-Views, data diolah 2018

\section{European Central Bank terhadap Yield Obligasi}

Suku bunga internasional yang diwakili oleh suku bunga Eropa memengaruhi secara negatif terhadap yield obligasi pemerintah sesuai pada gambar 8 . Hasil penelitian ini sesuai dengan temuan dari Vargas (2005) yang menemukan kenaikan The Fed merupakan indikasi adanya pertumbuhan di Amerika. Hal tersebut akan meningkatkan ekspektasi pertumbuhan ekonomi negara berkembang yang kemudian meningkatkan kinerja ekspor. Peningkatan kinerja ekonomi akan menurunkan yield obligasi.

Temuan lain juga menyatakan bahwa perubahan suku bunga internasional dapat memengaruhi aliran modal ke dalam negara berkembang (Min, 1998). Pada saat adanya kenaikan tingkat ECB, maka hal tersebut dapat membuat ekspektasi bahwa para investor asing akan mencari dananya pada pada negara-negara berkembang. Pada saat perekonomian berjalan baik, maka hal tersebut menunjukkan suatu negara dapat membayar hutang-hutangnya yang akibatnya harga obligasi akan naik dan yield-nya turun.

Dengan demikian, tingkat bunga Eropa (ECB) dapat memengaruhi secara negatif terhadap yield obligasi pemerintah jangka pendek, jangka menengah mau pun jangka panjang. Pada saat ECB mengalami kenaikan, maka hal tersebut dapat membuat yield obligasi pemerintah di semua tenor akan turun dan demikian pula sebaliknya. 

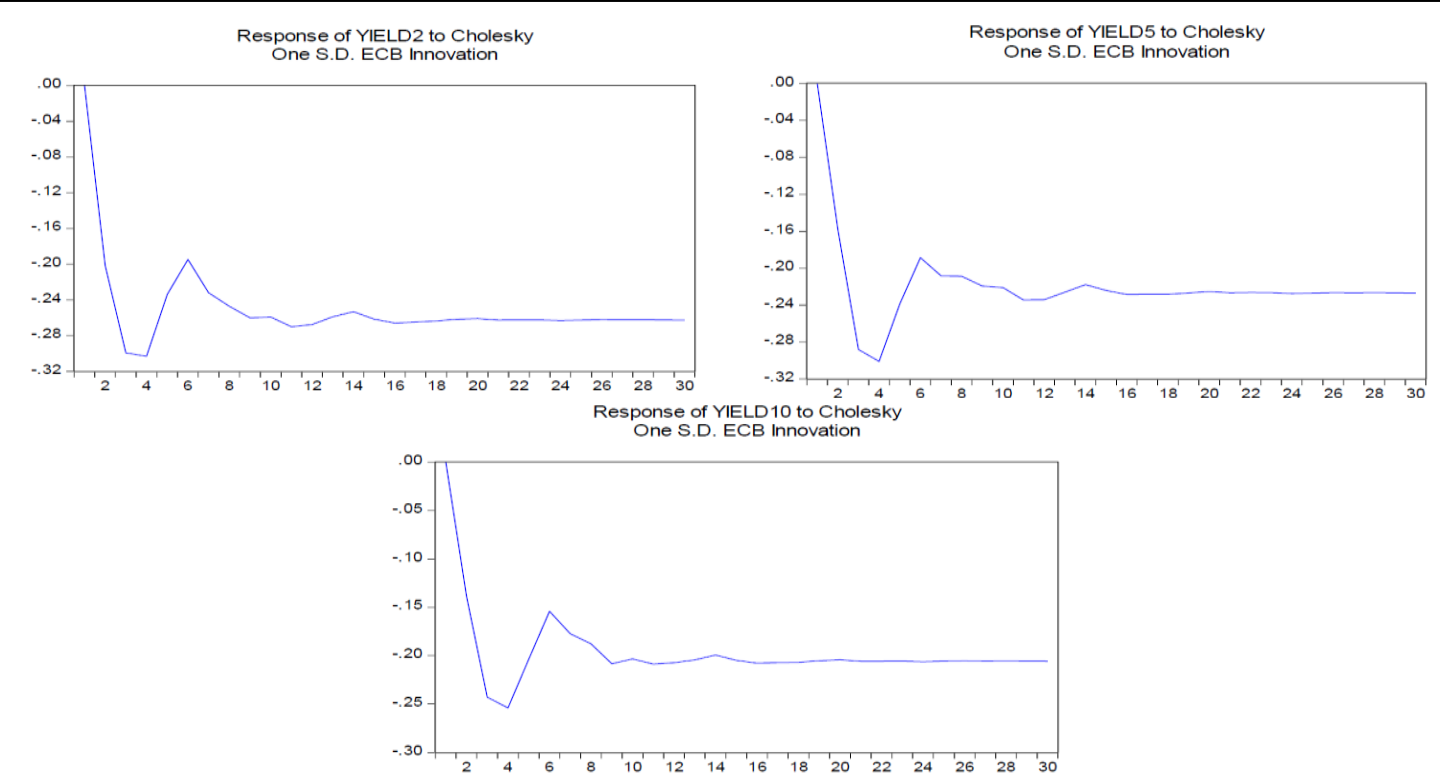

\section{Gambar 8. Pengaruh European Central Bank terhadap Yield Obligasi Pemerintah Indonesia}

Sumber: E-Views, data diolah 2018

Berdasarkan analisis Impulse Response Function (IRF) dapat diketahui bahwa pergerakan yield obligasi pemerintah yang disebabkan oleh faktor makro ekonomi, faktor likuiditas dan faktor eksternal sesuai dengan pola menurut teori harapan. Pergerakan yield untuk obligasi jangka pendek mau pun jangka panjang akan bergerak searah atau serupa karena ada harapan tingkat bunga obligasi jangka panjang sesuai dengan rata-rata tingkat bunga obligasi jangka pendek (Miskhin, 2009).

\section{Analisis Forecast Error Variance Decomposition (FEVD)}

Analisis FEVD di penelitian ini untuk membahas pengaruh faktor makro ekonomi, faktor likuiditas dan faktor eksternal terhadap yield obligasi pemerintah dengan menggunakan horizon waktu sepanjang 25 bulan. Analisis dengan menggunakan dekomposisi varian dapat memberikan informasi mengenai berapa persen kontribusi pengaruh masing-masing variabel terhadap variabel lainnya.

\section{FEVD Yield Tenor 2 Tahun}

Pada awal periode semua variabel bebas penelitian ini yang terdiri dari BI rate, CPI, M1, IHSG, CD dan ECB tidak memberikan pengaruh sekali pun terhadap yield obligasi tenor 2 tahun. Mulai periode ke 2, ke semua variabel bebas penelitian ini mulai memengaruhi yield tenor 2 tahun seperti yang terlihat pada tabel 2. Begitu pula BI rate, CPI, M1, IHSG, CD dan ECB mulai periode ke 20 sampai dengan seterusnya memberikan pengaruh yang konstan berturut-turut terhadap yield tenor 2 tahun pada kisaran $1,2 \% ; 4,5 \% ; 2,3 \%$; $0,7 \% ; 6,7 \%$ dan $11,3 \%$. Jika diurutkan, variabel yang memberikan kontribusi terbesar terhadap pergerakan yield obligasi tenor 2 tahun yaitu yield tenor 2 tahun itu sendiri dengan pengaruhnya sebesar sekitar $50,9 \%$. 
Tabel 2. Hasil FEVD untuk Yield 2 Tahun

\begin{tabular}{|c|c|c|c|c|c|c|c|}
\hline Period & YIELD2 & BIRATE & CPI & M1 & IHSG & $\mathrm{CD}$ & ECB \\
\hline 1 & 0.498852 & 0.000000 & 0.000000 & 0.000000 & 0.000000 & 0.000000 & 0.000000 \\
\hline 2 & 0.566513 & 0.016229 & 0.001068 & 0.023654 & 0.014646 & 0.069845 & 0.125346 \\
\hline 3 & 0.529300 & 0.000777 & 0.024748 & 0.027571 & 0.020859 & 0.077841 & 0.115633 \\
\hline 4 & 0.531566 & 0.008717 & 0.044078 & 0.027905 & 0.000136 & 0.066213 & 0.110742 \\
\hline 20 & 0.509077 & 0.012160 & 0.045353 & 0.023495 & 0.007033 & 0.067505 & 0.113033 \\
\hline 21 & 0.509092 & 0.012182 & 0.045384 & 0.023526 & 0.006996 & 0.067454 & 0.113056 \\
\hline 22 & 0.509059 & 0.012172 & 0.045367 & 0.023510 & 0.007011 & 0.067461 & 0.113073 \\
\hline 23 & 0.509065 & 0.012165 & 0.045359 & 0.023501 & 0.007023 & 0.067484 & 0.113054 \\
\hline 24 & 0.509079 & 0.012173 & 0.045371 & 0.023513 & 0.007011 & 0.067471 & 0.113053 \\
\hline 25 & 0.509070 & 0.012173 & 0.045370 & 0.023513 & 0.007010 & 0.067465 & 0.113063 \\
\hline
\end{tabular}

Cholesky Ordering: YIELD2 BIRATE CPI M1 IHSG CD ECB

Sumber: E-Views, data diolah 2016

\section{FEVD Yield Tenor 5 Tahun}

Berdasarkan tabel 3 dapat diketahui bahwa semua variabel bebas di penelitian ini yang terdiri dari $\mathrm{BI}$ rate, $\mathrm{CPI}, \mathrm{M} 1$, IHSG, CD dan ECB tidak memengaruhi yield obligasi pemerintah jangka menengah pada awal periode. Namun, pada periode ke 2 justru semua variabel bebas tersebut mulai memengaruhi yield obligasi tenor 5 tahun. Pada periode ke 20 sampai dengan seterusnya, BI rate, CPI, M1, IHSG, CD dan ECB mulai memberikan pengaruh secara konstan terhadap yield 5 tahun masing-masing sebagai berikut $0,1 \% ; 3,3 \%$; $1,5 \% ; 0,3 \% ; \quad 6,4 \%$ dan $6,8 \%$. Jika diurutkan, variabel yang memberikan kontribusi terbesar terhadap pergerakan yield obligasi tenor 5 tahun yaitu yield tenor 5 tahun itu sendiri dengan pengaruhnya sebesar sekitar 49,1\%.

Tabel 3. Hasil FEVD untuk Yield 5 Tahun

\begin{tabular}{|c|c|c|c|c|c|c|c|}
\hline Period & YIELD5 & BIRATE & CPI & M1 & IHSG & $\mathrm{CD}$ & ECB \\
\hline 1 & 0.490795 & 0.000000 & 0.000000 & 0.000000 & 0.000000 & 0.000000 & 0.000000 \\
\hline 2 & 0.547895 & 0.019311 & 0.001595 & 0.027487 & 0.020183 & 0.058964 & 0.076020 \\
\hline 3 & 0.503885 & 0.016727 & 0.010745 & 0.010763 & 0.019156 & 0.077603 & 0.073235 \\
\hline 4 & 0.508734 & 0.005866 & 0.031373 & 0.018027 & 0.001701 & 0.068967 & 0.063146 \\
\hline 20 & 0.491126 & 0.001115 & 0.033549 & 0.015416 & 0.003749 & 0.064674 & 0.068049 \\
\hline 21 & 0.491135 & 0.001090 & 0.033586 & 0.015448 & 0.003714 & 0.064630 & 0.068055 \\
\hline 22 & 0.491114 & 0.001094 & 0.033576 & 0.015441 & 0.003723 & 0.064624 & 0.068069 \\
\hline 23 & 0.491119 & 0.001105 & 0.033563 & 0.015428 & 0.003736 & 0.064648 & 0.068060 \\
\hline 24 & 0.491127 & 0.001098 & 0.033573 & 0.015437 & 0.003726 & 0.064641 & 0.068057 \\
\hline 25 & 0.491121 & 0.001096 & 0.033575 & 0.015439 & 0.003724 & 0.064632 & 0.068062 \\
\hline
\end{tabular}

Cholesky Ordering: YIELD5 BIRATE CPI M1 IHSG CD ECB

Sumber: E-Views, data diolah 2018 


\section{FEVD Yield Tenor 10 Tahun}

Tabel 4 menunjukkan bahwa BI rate, $\mathrm{CPI}, \mathrm{M} 1$, IHSG, $\mathrm{CD}$ dan $\mathrm{ECB}$ tidak memengaruhi yield obligasi tenor 10 tahun pada awal periode. Dimulai periode ke 2 dan seterusnya semua variabel bebas di penelitian ini mulai memberikan pengaruh terhadap yield obligasi pemerintah jangka panjang. Pada awal periode ke 20 dan seterusnya BI rate, CPI, M1, IHSG, CD dan ECB memengaruhi yield 10 tahun secara konstan dengan masing-masing kontribusi pengaruhnya sebagai berikut $0,05 \%$; $0,06 \% ; 1,9 \% ; 1 \% ; 6,3 \%$ dan $5,7 \%$. Variabel yang memberikan kontribusi terbesar terhadap pergerakan yield obligasi tenor 10 tahun yaitu yield tenor 10 tahun itu sendiri dengan pengaruhnya sebesar sekitar $44,5 \%$.

Tabel 4. Hasil FEVD untuk Yield 10 Tahun

\begin{tabular}{|c|c|c|c|c|c|c|c|}
\hline Period & YIELD10 & BIRATE & CPI & M1 & IHSG & $\mathrm{CD}$ & ECB \\
\hline 1 & 0.472330 & 0.000000 & 0.000000 & 0.000000 & 0.000000 & 0.000000 & 0.000000 \\
\hline 2 & 0.499684 & 0.020596 & 0.019161 & 0.013138 & 0.040858 & 0.050196 & 0.069079 \\
\hline 3 & 0.448414 & 0.022289 & 0.028410 & 0.029749 & 0.012206 & 0.084990 & 0.064575 \\
\hline 20 & 0.445577 & 0.000560 & 0.000589 & 0.019887 & 0.010062 & 0.063611 & 0.057794 \\
\hline 21 & 0.445563 & 0.000582 & 0.000613 & 0.019860 & 0.010083 & 0.063567 & 0.057806 \\
\hline 22 & 0.445552 & 0.000572 & 0.000597 & 0.019874 & 0.010064 & 0.063577 & 0.057809 \\
\hline 23 & 0.445563 & 0.000567 & 0.000594 & 0.019879 & 0.010063 & 0.063592 & 0.057802 \\
\hline 24 & 0.445563 & 0.000574 & 0.000603 & 0.019871 & 0.010072 & 0.063581 & 0.057804 \\
\hline 25 & 0.445558 & 0.000573 & 0.000600 & 0.019872 & 0.010068 & 0.063579 & 0.057806 \\
\hline
\end{tabular}

Cholesky Ordering: YIELD10 BIRATE CPI M1 IHSG CD ECB

Sumber: E-Views, data diolah 2018

Dari hasil uji FEVD, pergerakan yield obligasi pemerintah untuk semua tenor lebih disebabkan oleh yield obligasi itu sendiri. Faktor makro ekonomi, faktor likuiditas dan faktor eksternal memberikan kontribusi terhadap pergerakan yield obligasi pemerintah tetapi kontribusinya kecil. Dari pernyataan tersebut, tingkat kupon obligasi pemerintah itu sendiri dapat memberikan kontribusi terbesar terhadap pergerakan yield obligasi pemerintah.

\section{SIMPULAN DAN SARAN}

\section{Simpulan}

Yield obligasi pemerintah Indonesia untuk tenor jangka pendek, jangka menengah dan jangka panjang akan bergerak secara fluktuatif karena disebabkan oleh semua variabel yang terdapat pada faktor makro ekonomi, faktor likuiditas dan faktor eksternal. Berarti ke semua faktor tersebut dapat digunakan untuk meramalkan pergerakan yield obligasi pemerintah Indonesia di semua tenor.

Yield obligasi pemerintah pada semua tenor akan mengalami peningkatan ketika fundamental makro ekonomi seperti inflasi, jumlah uang beredar dan IHSG mengindikasikan sedang mengalami penurunan. Sebaliknya, kebijakan moneter ketat yang menyebabkan penurunan BI rate dapat membuat yield obligasi turut turun.

Para pihak terkait obligasi pemerintah Indonesia harus memerhatikan kebijakan fiskal mau pun kebijakan moneter yang diterapkan oleh pemerintah Indonesia. Kebijakan-kebijakan tersebut 
dapat menyebabkan perubahan pada fundamental makro ekonomi Indonesia yang nantinya yield obligasi akan turut terpengaruh.

Kondisi eksternal yang terjadi di luar Indonesia seperti kenaikan tingkat bunga acuan di Eropa dapat menyebabkan yield obligasi semakin rendah. Namun sebaliknya, meningkatnya kemampuan likuiditas yang dimiliki oleh pemerintah Indonesia yang diwakili oleh cadangan devisa justru menyebabkan yield obligasi yang ditetapkan oleh pemerintah Indonesia semakin besar.

Dari hasil uji IRF, pola pergerakan yield obligasi pemerintah Indonesia di semua tenor selama periode pengamatan telah sesuai dengan teori harapan. Artinya perilaku investor terhadap obligasi di semua tenor akan sama saja. Hal tersebut terjadi karena mereka menganggap hasil yang akan diperoleh sama saja dengan berinvestasi pada obligasi jangka pendek, jangka menengah mau pun jangka panjang.

Dari hasil uji FEVD, studi ini juga menemukan bahwa yang memberikan kontribusi terbesar terhadap fluktuasi yield obligasi pemerintah jangka pendek, jangka menengah mau pun jangka panjang adalah yield itu sendiri. Hal ini menunjukkan bahwa besaran kupon atau tingkat bunga dari obligasi pemerintah menentukan pergerakan yield itu sendiri.

\section{Saran}

Kontributor terbesar terhadap pergerakan yield obligasi pemerintah untuk semua tenor selama periode penelitian ini adalah yield obligasi itu sendiri. Pemerintah harus menetapkan kupon obligasi yang akan diterbitkan secara tepat. Penetapan kupon obligasi selanjutnya dapat dilakukan dengan melihat tipe investor selama periode pengamatan. Menurut hasil penelitian ini, tipe investor selama periode pengamatan lebih terkait dengan teori harapan. Jika pemerintah menginginkan harga obligasi jangka panjang yang tinggi, maka pemerintah dapat menetapkan kupon obligasi jangka pendek yang rendah. Hal tersebut mengakibatkan kupon obligasi jangka panjang juga akan rendah yang akibatnya yield obligasi jangka panjang turun dan harganya akan naik.

Pada saat BI rate dan cadangan devisa naik, maka yield obligasi pemerintah di semua tenor akan turut naik dan kemudian harga obligasi akan turun. Para investor dapat menjual surat obligasi pemerintah di semua tenor ketika ada indikasi tersebut untuk menghindari jatuhnya harga obligasi. Hasil penelitian ini juga menemukan bahwa ketika inflasi, JUB, IHSG dan tingkat bunga Eropa naik, maka yield obligasi pemerintah semua tenor akan turun. Oleh karena itu investor dapat segera membeli obligasi pemerintah di tenor mana pun, ketika ada indikasi tersebut.

\section{Keterbatasan Penelitian}

Penelitian ini hanya terbatas meramalkan determinan yield obligasi pemerintah dalam denominasi Rupiah, walau pun obligasi pemerintah dapat diukur juga dalam denominasi Dollar. Beberapa penelitian yang terkait dengan yield obligasi menyertakan variabel nilai tukar sebagai salah satu faktor pengaruh pergerakan yield obligasi. Oleh karena itu nilai tukar merupakan variabel yang penting, maka sebaiknya digunakan pada penelitian selanjutnya.

\section{Agenda Penelitian Mendatang}

Penelitian berikutnya tentang yield obligasi pemerintah dapat dilakukan terhadap yield Obligasi Ritel Indonesia (ORI) karena ORI merupakan instrumen obligasi yang lebih murah dibandingkan Obligasi Negara (ON). Oleh karena itu penelitian tentang yield obligasi pemerintah jika difokuskan pada jenis ORI, maka hasil penelitian lebih dapat berkontribusi bagi banyak pihak. Penelitian mendatang dapat juga meneliti determinan yield obligasi pemerintah dalam denominasi Dollar. Variabel-variabel bebas yang akan diteliti selanjutnya dapat menggunakan variabel penelitian lain yang diperkirakan dapat memengaruhi yield obligasi seperti nilai tukar. 


\section{DAFTAR PUSTAKA}

Baldacci, E., Gupta, S., dan Mati, A. (2008). Is it (still) mostly fiscal? Determinants of sovereign spreads in emerging markets. IMF Working Paper. 08 (259): 1-23

Batten, J. A., Fetherston, T. A., dan Hoontrakul, P. (2006). Factors affecting the yields of emerging market issuers: Evidence from the Asia-Pacific region. Journal of International Financial Markets, Institutions and Money. Vol 16: 57-70.

Budina, N., dan Mantchev, T. (2000) Determinants of bulgarian brady bond prices: an empirical assessment. World Bank Policy Research Working Paper. 2277: 130.

Chionis, D., Pragidis, I., dan Schizas, P. (2014). The Determinants of Greek Bond Yield: An Empirical Study Before and During the Crisis. Journal of Ecnomic Studies. Vol 43 (3): 504-519.

Cochrane, J. (2001). Asset pricing. New Jersey: Princeton University Press.

Dewachter, H., Lyrio, M., dan Maes, K. (2006). A joint model for the term structure of interest rates and the macroeconomy. Journal of Applied Econometrics. Vol 20 (4): 439-462.

Eichengreen, B., dan Mody, A. (1998) What explains changing spreads on emerging-market debt? fundamentals or market sentiment?. NBER Working Paper. 6408: 107134.

Fah, C. F. (2008). Macroeconomics determinants of Malaysian Government Securities (MGS) spread. Paper Presented during Proceeding of The MFA Conference 2008. Kuching, Sarawak.
Gandhi, D. V. (2006). Pengelolaan cadangan devisa di Bank Indonesia. Jakarta: Pusat Pendidikan dan Studi Kebanksentralan (PPSK) BI.

Jurksas, L., dan Kropiene, R. (2014). Macroeconomics determinants of Lithuanian government security prices. Ekonomika, Vol 93 (4).

$\mathrm{Li}$, J. (2006). The Effect on Monetary Policy on the Correlation between Stock and Bond Markets (Dissertation).

http://www.pages.drexel.edu/ j1383 /online_papers.htm

Min, H. G. (1998). Determinants of emerging market bond spread: Do Economic fundamentals matter? World Bank Policy Research Working Paper. No. 1899: 1-31.

Miskhin, F. S. (2009). The Economics of money, banking and financial market. $9^{\text {th }}$ Ed. New York: Pearson Education.

Piesse, J., Israsena, N., dan Thirtle, C. (2007). Volatility transmission in Asia bond markets: Test of portofolio diversification. Asia Pacific Business Review. Vol 13: 585-607.

Sihombing, P. (2014). Determinan yield curve Surat Utang Negara (SUN). Disertasi. Bogor: IPB.

Stander, Y. S. (2005). Yield curve modelling. New York: Palgrave Macmillan.

Vargas, G. A. (2005). Macroeconomic determinants of the movement of the yield curve. MPRA Paper. 53117: 1-14.

Verbeek, M. (2000). A guide to modern Econometrics. New York: Wiley.

www.djppr.kemenkeu.go.id (situs resmi Direktorat Jenderal Pengelolaan Pembiayaan dan Risiko - DJPPR Kemenkeu, diambil per Februari 2017). 